\title{
THE EFFECTIVENESS OF CREATIVE PROBLEM SOLVING ON LOGICAL THINKING ABILITY AND MASTERY OF CONCEPTS
}

\author{
Dina Shafina $^{1}$, Dewi Lengkana ${ }^{2}$, Tri Jalmo ${ }^{3}$, Dina Maulina ${ }^{4}$ \\ 1,2,3,4 Program Studi Pendidikan Biologi, Fakultas Keguruan dan Ilmu Pendidikan, Universitas Lampung \\ Bandar Lampung, 35145, Indonesia \\ 4dina.maulina@fkip.unila.ac.id
}

DOI:

\begin{abstract}
This research aims to determine the effect of Creative Problem Solving (CPS) on logical thinking ability and concept achievement. The design was a nonequivalent pretest-posttest control group design. The samples were 60 students of $\mathrm{X}$ MIA 1 and X MIA 3 selected through cluster random sampling technique. Data on logical thinking ability obtained using the Test of Logical Thinking (TOLT and data on concept achievement (cognitive aspects) gathered using pretest and posttest. Both data were analyzed by Independent Sample t-Test at a 5\% confidence level. The results showed that CPS give effect significantly the experimental class logical thinking ability $(0.41 \pm 0.13)$ was higher than the control class $(0.21 \pm 0.07)$. The mastery of concepts on the experiment class $(0.61 \pm 0.20)$ higher than the control class $(0.41 \pm$ 0.20 ). It means that CPS influences students' logical thinking ability and mastery of concepts.
\end{abstract}

Keywords: Logical Thinking Ability, mastery of concepts, Creative Problem Solving (CPS).

\footnotetext{
${ }^{4}$ Corresponding Author
} 


\section{Introduction}

The development of science and technology makes life enter a new era, namely the era of information and globalization. The progress of science and technology with the diversity of challenges and demands requires people who have competitiveness with the ability to think logically, critically, and creatively (Sumarmo, 2010). One of ability to believe that always considered in one's life in action is the ability to think logically. The ability to think logically affects human beings in other mental processes, such as critical and creative thinking. That is because logical thinking can provoke someone to think critically and creatively when facing a problem. Logical thinking makes students do reasoning in building various thoughts to solve a problem correctly (Andriawan, 2014).

Learning activities must equip students with the ability to think logically, as a form of achieving competence in supporting daily activities and supporting success in the future (Kemdikbud, 2013: 1). Based on the need for logical thinking activities in learning, the data shows that SMAN 1 Jati Agung has low learning outcomes achieved by 61 students, with a value of 75 as KKM. Observations in the form of interviews that carried out obtained results that the ability of students in solving problems related to the principles of logic and drawing conclusions is low. Students in the tenth grade are only able to solve problems, if given a different problem of examples, only $40 \%$.

Students' logical thinking skills are still of poor quality. Many students are not able to work on problems using their logical thinking skills (Swestyani et al., 2015). Learners find it difficult to define a problem, lack many ideas, and find. It is challenging to get rid of inefficient alternatives, not determine the ideal choice or option, and not know the effects and effects of solving a problem. They are slow in solving problems. It shows the low ability of logical thinking students addresses the issues. Students' logical thinking skills can be developed by conducting learning activities in groups because of groups. Students are faced with challenges to find solutions to the topics they are studying. Students can work together with their peers in one task. Students can develop the strength to search for and find materials to carry out these tasks in logical thinking (Mulyani, 2018).

The inappropriate implementation of learning models becomes to be one of the factors causing the low ability of thinking and understanding of participants. Conventional learning methods through lectures dominate learning activities. This form of narrow learning results in student's only accepting information provided by educators without being supported by other relevant information. This form of learning trains students to be passive and not involved in the learning process. The learning model is strongly influenced by the problem of the material to teach, the objectives to achieve in teaching, and the ability level of students (Trianto, 2014).

The learning model is very important in efforts to improve logical thinking skills and learning outcomes. It needs more actively involves students in the learning process itself. Creative Problem Solving (CPS) is a learning model that sharpens problem-solving skills, followed by strengthening skills with problem-solving. Students can generate interest as well as creativity and motivation in learning, especially biology subjects. Students can get the maximum benefit, both from the process and the results of education (Prastiwi, 2018).

Creative Problem-Solving trains students to have students' logical thinking skills in problemsolving. When faced with a problem, students can solve the problem and choose to develop their responses through resolution. Not only remembering knowledge but also involves problem-solving skills and broadening the thought process (Busyari \& Sinaga, 2015).

The CPS learning model trains students to develop their thinking skills, solve problems and intellectual capabilities so that students can empower, hone, test, and develop their thinking abilities continuously. The ability to think supports solving a problem in the ability to think logically (Rusman, 2012). The results of research conducted by Mulyani (2018) show that the application of the CPS model has a significant effect on students' logical thinking. In addition, Hartantia (2013) proved that the implementation of the CPS model could improve student learning outcomes. Thus, CPS becomes an alternative to develop logical thinking skills.

Biology specifically emphasizes authentic problems that occur in the environment in everyday life. The ability to think logically is needed to solve problems. Implementation of a learning center on the habit of logical thinking will help students deal with various phenomena in everyday life. The ecosystem is one of the materials in the biology curriculum that is closely related to problems that occur in real life. 
Therefore, ecosystem material is appropriate to be applied with the CPS model to improve students mastery of concepts and logical thinking.

\section{Research Methods}

This research is a quasi-experimental study with nonequivalent pretest-posttest control group design, which is the type of design that uses in experiments that use classes that already exist as a group, by selecting classes that are estimated in the same conditions. The design of this study consisted of two groups: the experimental group and the control group (Sugiyono, 2010) (see table 1).

Table 1. Nonequivalent pretest-posttest control group design

\begin{tabular}{cccc}
\hline Group & Pretest & Treatment & Posttest \\
\hline $\mathrm{E}$ & $\mathrm{O}_{1}$ & $\mathrm{X}$ & $\mathrm{O}_{2}$ \\
$\mathrm{~K}$ & $\mathrm{O}_{3}$ & $\mathrm{Y}$ & $\mathrm{O}_{4}$ \\
\hline
\end{tabular}

Information:

O1, O3 = Pretest

$\mathrm{E}=$ Experiment group

$\mathrm{K}=$ Control group

$\mathrm{X}=$ Treatment in experiment class with CPS

$\mathrm{Y}=$ Treatment in control class

$\mathrm{O} 2, \mathrm{O} 4=$ Posttest

The population is all 10th-grade students in SMA Negeri 1 Jati Agung, academic year 2019/2020. The sampling technique in this study was carried out by cluster random sampling technique, namely students in class 10 MIA 1, amounting to 30 people as an experimental class and class 10 MIA 3 totaling 30 people as a control class.

\section{Test of Logical Thinking (TOLT).}

This test adopted from the development of Tobin and Cappie test kits, subsequently modified according to research needs on ecosystem teaching materials. The test questions consist of 8 items in the form of written tests with illustrations of problems and answers in the form of multiple choices accompanied by reasons.

Data retrieval is done by the Test of Logical Thinking (TOLT). The test used to measure the logical thinking ability based on indicators. The indicators consist of controlling variables, probabilistic reasoning, correlational reasoning, combinatorial reasoning, and proportional reasoning. Data in the form of concept mastery used to determine the level of understanding of students related to the material being taught. The learning outcome data is obtained from the pretest, posttest, and $\mathrm{N}$-gain values with the scoring guidelines in table 2 .

\section{The Effectiveness of Creative Problem Solving}

Table 2. Scoring guidelines test logical thinking skills

\begin{tabular}{llc}
\hline No & Question Answer Criteria & Score \\
\hline 1 & Correct answer and reason & 4 \\
2 & Correct answer and wrong reason & 3 \\
3 & Wrong answer and correct reason & 2 \\
4 & Wrong answer and reason & 1 \\
5 & No answer and reason & 0 \\
\hline
\end{tabular}

Scores obtained from test results are converted into values with a vulnerable 0-100, using the formula1.

$$
S=\frac{\mathrm{R}}{\mathrm{N}} \times 100
$$

Information

$\mathrm{S}=$ Expected value

$\mathrm{R}=$ The total score of the item answered is correct.

$\mathrm{N}=$ Maximum number of scores

(Purwanto, 2008).

The data of logical thinking ability tests are grouped according to the categories in table 3.

Table 3. Category of Logical Thinking Ability

\begin{tabular}{lll}
\hline No & Score & Category \\
\hline 1 & $0 \leq X<20$ & Very low \\
2 & $20 \leq X<40$ & Low \\
3 & $40 \leq X<60$ & Medium \\
4 & $60 \leq X<80$ & High \\
5 & $80 \leq X<100$ & Very high \\
\hline
\end{tabular}

\section{Result and Discussion}

Assessment of learning outcomes obtained through pretest and posttest in the form of questions on the test questions about knowledge of ecosystem material is based on the content, and the extent is adjusted to Basic competence 3.10 Biology 10th grade high school, namely: Analyzing the components of ecosystems and interactions between these components. Improved students 'logical thinking ability is obtained because the use of CPS learning models significantly influences the increase in students' logical thinking skills. CPS is one model that is considered adequate and can help solve various problems in daily life (Triyono, 2016).

Stages of problem finding, students can identify all statements given the problem to be solved. Giving a problem will train and familiarize students with thinking activities. That happens because a problem cannot be solved without a thinking process. The thinking process will train ideas precisely and thoroughly. Learners process information to be used as consideration of their 


\section{Shafina, Lengkana, Jalmo, Maulina}

minds in finding solutions to these problems. The reasoning of this mind then leads them to think logically, because students think in a way that makes sense based on the facts that are in the problem they are going to solve. That will lead to thinking logically in a way that is reasonable based on the facts that exist in the problem they will solve (Huda, 2014).

The student worksheet based on problemsolving leads students to think logically. Learning activities in group's help students find solutions to the topics they are learning. Students can work together with their peers through this group discussion students can develop the strength to search for and carry out these tasks in logical thinking (Mulyani, 2018).
The results of the pretest, posttest, and $\mathrm{N}$-gain tests of logical thinking and mastery of students in the experiment and control classes are presented in Tables 4 and 5. Hypothesis testing for mastery of concepts is done using the Independent Sample ttest (to test the significance of the average difference in two classes, namely the experimental and control classes). Based on Tables 4 and 5, it appears that the value of sig. (2-tailed) is less than 0.05 , which means the average logical thinking and mastery of students' concepts between the experiment and control classes are significantly different. That means the decision to accept H1, which means that the average experiment class is higher than the control class. These results indicate the influence of CPS learning on logical thinking skills and mastery concepts.

Table 4. Result of Test of Logically Thinking (TOLT)

\begin{tabular}{|c|c|c|c|c|c|}
\hline & Class & $\bar{X} \pm$ Sd & Normality test & Homogeneity test & Independent $\mathrm{T}$-Test \\
\hline \multirow[t]{2}{*}{ Pretest } & $\mathrm{C}$ & $15,80 \pm 3,13$ & Sig. $0,13>0,05$ & Sig. $0,18>0,05$ & \\
\hline & $\mathrm{E}$ & $16,00 \pm 2,77$ & Sig. $0,18>0,05$ & & Sig. (2-tailed) \\
\hline \multirow[t]{2}{*}{ Posttest } & $\mathrm{C}$ & $19,40 \pm 2,49$ & Sig.0,81>0,05 & Sig. $0,96>0,05$ & $0,000<0,05$ \\
\hline & $\mathrm{E}$ & $22,56 \pm 2,51$ & Sig. $0,18>0,05$ & & \\
\hline \multirow[t]{2}{*}{$\mathrm{N}$-gain } & $\mathrm{C}$ & $\begin{array}{l}0,21 \pm 0,07 \\
\text { (Low) }\end{array}$ & Sig. $0,12>0,05$ & Sig. $0,31>0,05$ & \\
\hline & $\mathrm{E}$ & $\begin{array}{l}0,41 \pm 0,13 \\
\text { (Medium) }\end{array}$ & Sig.0,17>0,05 & & \\
\hline
\end{tabular}

Table 5. Result of Mastery Concept

\begin{tabular}{|c|c|c|c|c|c|}
\hline & Class & $\bar{X} \pm$ Sd & Normality Test & Homogeneity Test & Independent $\mathrm{T}$-Test \\
\hline \multirow[t]{2}{*}{ Pretest } & $\mathrm{C}$ & $38,7 \pm 17,47$ & Sig. $0,13>0,05$ & & \multirow{4}{*}{$\begin{array}{c}\text { Sig. }(2 \text {-tailed }) \\
0,001<0,05\end{array}$} \\
\hline & $\mathrm{E}$ & $40,83 \pm 18,55$ & Sig. $0,15>0,05$ & $\operatorname{Sig} 0,57>0,05$ & \\
\hline \multirow[t]{2}{*}{ Posttest } & $\mathrm{C}$ & $64,5 \pm 16,44$ & Sig. $0,81>0,05$ & \multirow{2}{*}{ Sig $0,64>0,05$} & \\
\hline & $\mathrm{E}$ & $75,4 \pm 15,90$ & Sig. $0,60>0,05$ & & \\
\hline \multirow[t]{2}{*}{ N-gain } & $\mathrm{C}$ & $\begin{array}{l}0,41 \pm 0,20 \\
\text { (Low) }\end{array}$ & Sig. $0,14>0,05$ & \multirow{2}{*}{ Sig $0,88>0,05$} & \\
\hline & $\mathrm{E}$ & $\begin{array}{l}0,61 \pm 0,20 \\
\text { (Medium) }\end{array}$ & Sig. $0,15>0,05$ & & \\
\hline
\end{tabular}

The success in using CPS to increase mastery of learners' concepts is strengthened by the achievement of indicators presented to test how broad the students understanding of the material has been learned. At the stage of solution-finding, students choose a solution to decide on a conclusion that has the correct possibility. Thinking skills are considered as cognitive learning skills and show the skills and mental processes involved in learning actions, such as remembering and understanding facts or ideas (Yuliati \& Lestari, 2019).

Learning with thinking process directed to solve problems is focused on an effort to explore students. The meaning of the thinking process in the event of mixing, matching, combining, exchanging, and sorting concepts, perceptions, and previous experiences. The cognition or thinking process is related to the explanation of the things that happen to students' brains that occur during the acquisition of new knowledge, namely how the new knowledge is obtained, organized, stored in memory, and used further in learning to problemsolve (Oktaviani \& Nugroho, 2015).

Learning to use CPS in the experimental class begins with the presentation of problems designed in a context that is relevant to the material to be learned namely basic competencies 3.10. The context of the problem presented includes materials that occur in ecosystems in Indonesia specifically, such as oil spills belonging to PT. Pertamina in Balikpapan Bay, forest fires, damage to the paddy ecosystem, and pollution of the Citarum river. The problem presented is actually a context that does occur in the real world. Human reliability in solving various problems enables 


\section{The Effectiveness of Creative Problem Solving}

humans to adapt and change their environment to survive.

Based on problems related to problems that occur in real life, students and group friends put forward the most effective solution to overcome these problems through logical thinking. The student worksheets provided fulfill the competencies required by the curriculum. Learners analyze what components and interactions occur when the ecosystem with different thoughts.

Stage of thinks in the context of CPS is done through the presentation of problems in the form of discourse in student worksheets, then the first stage they do with a group of friends, namely objective finding. This stage is an attempt to identify situations that present a challenge. At this stage, students write down the subject matter and formulate questions that arise in their minds on the discourse presented.

Furthermore, students entered at the data finding stage. The stage of finding facts by identifying all facts related to the situation presented. It aims to find information that is unknown but important to look for. At this stage, students write down facts related to ecosystem material, namely writing biotic and abiotic components. Then, students enter the problemfinding stage. Students can identify all statements of problems that have been found. In the final stage, students can choose the most important or fundamental problem to be solved and related to the material being studied.

Logical thinking can be realized through CPS stages that begin with the idea finding stage. This stage is the process of finding a number of ideas that might be used to solve a problem. Learners write down any ideas that can solve the problems, they have written down in the previous problem. Next, students enter the stage of finding a solution. At the solution discovery stage, ideas that have been obtained in the previous stage are selected to find the most appropriate ideas in solving problems. At this stage, students choose one of the most appropriate solutions to solve the problems they have also chosen in the previous stage. The final stage of CPS conducted by students is the stage of finding acceptance. This stage is an attempt to obtain acceptance of the solution to the problem, formulate an action problem to implement the chosen solution. The effort made by these students is made by presenting the results of their ideas.

Researches in the experimental class using the CPS, students are allowed to develop their ability to think logically in problem-solving, followed by strengthening other skills. Problem-solving skills acquired by students play a role in choosing and developing their responses through given problems and linking them with the material to be learned.

In addition, the problem-solving process can improve understanding of concepts because students gain knowledge from the results of their thinking. As stated by Amalia (2011), the knowledge obtained themselves is relatively easier to remember and understand than the knowledge gained from the results of lectures conducted informatively.

Students in the experimental class have higher logical thinking skills than the control class. These findings are in line with research conducted by Mulyani (2018) that there is an influence of the use of CPS on logical thinking skills. Besides, Solfitri's research (2014) suggests that the use of CPS has a significant effect on scores on cognitive learning outcomes. It shows the importance of choosing the right learning model to train students' thinking skills. The process of selecting a learning model involves a process of analysis of the curriculum and student background. Stages in CPS become an alternative to train students to think logically, mastery of concepts, and problemsolving.

\section{Conclusion}

The CPS model has a significant effect on the ability of logical thinking and mastery of students' concepts. The significance value is smaller than 0.05. It shows that each stage of CPS can train students' logical thinking and mastery of concepts. CPS is a stage that can be taught to students, especially to train students' thinking skills and mental processes.

\section{References}

Amalia, F. R. (2011). Pengembangan Tes Keterampilan Problem Solving Siswa SMA pada Materi Pokok Hidrolisis Garam. Skripsi. UPI Bandung. Tidak diterbitkan.

Andriawan, B. (2014). Identifikasi Kemampuan Berpikir Logis Dalam Pemecahan Masalah Matematika Pada Siswa Kelas VIII-1 SMP Negeri 2 Sidoarjo". Jurnal Ilmiah Pendidikan Matematika,3 (2): hal 42-48.

Busyari, A. \& Sinaga, P. (2015). Strategi pembelajaran creative problem solving (CPS) berbasis eksperimen untuk meningkatkan kemampuan kognitif dan 


\section{Shafina, Lengkana, Jalmo, Maulina}

keterampilan berpikir kreatif. Jurnal pengajaran MIPA. 20 (2): 133-143.

Huda, M. (2014). Model-Model Pengajaran dan Pembelajaran. Yogyakarta: Pustaka Pelajar.

Kemendikbud. (2013). Kerangka Dasar Kurikulum 2013. Kementerian Pendidikan dan Kebudayaan Direktorat Jenderal Pendidikan Dasar. Jakarta.

Mulyani, S. (2018). Pengaruh Model Creative Problem Solving terhadap Kemampuan Berpikir Logis Matematis Siswa di SMA N 3 Banda Aceh. Maju: Jurnal Ilmiah Pendidikan Matematika, 5: 2. Pp: 14-28 hlm.

Oktaviani \& Nugroho. (2015). Penerapan model model pembelajaran creative problem solving (CPS) pada pembelajaran kalor untuk meningkatkan pemahaman konsep dan keterampilan komunikasi. Unnes Physics Education Journal. 4(1): 27-31.

Prastiwi, M. (2018). Kemampuan pemecahan masalah pada siswa kelas VII SMP. Ejurnalpensa. 6(2), hlm 98-103.

Purwanto. (2008). Metodologi Penelitian Kuantitatif. Yogyakarta: Pustaka Pelajar.

Rusman. (2012). Model-Model Pembelajaran. Jakarta: Rajawali Pers.

Solfitri, T. (2014). Penerapan Model Pembelajaran Creative Problem Solving (CPS) Untuk Meningkatkan Hasil Belajar Matematika Siswa Kelas X IPA 1 Man 2 Model Pekanbaru. Al-Khwarizmi, 2: 2. Pp: 1-14 hlm.

Sugiyono. (2010). Metode Penelitian Pendidikan Pendekatan Kuantitatif, kualitatif, dan R\&D. Bandung: Alfabeta.

Sumarmo, U. (2010). Berpikir dan Disposisi Matematik: Apa, Mengapa, dan Bagaimana Dikembangkan pada Peserta Didik. Bandung: FPMIPA UPI.

Swestyani, S., Rinanto, Y., \& Widoretno, S. (2015). Peningkatan Kemampuan Berpikir Logis Melalui Penerapan Discovery Learning pada Materi Sistem Reproduksi di Kelas XI MIA 1 SMA Batik 2 Surakarta Tahun Pelajaran 2014/2015. Jurnal Pendidikan Biologi, 7 (3): 78-87.
Trianto. (2014). Model Pembelajaran Terpadu : Konsep, Strategi, dan Implementasinya dalam Kurikulum Tingkat Satuan Pendidikan (KTSP). Jakarta: Bumi Aksara.

Triyono. (2016). Pengaruh Pembelajaran IPA Berbasis Creative Problem Solving terhadap Literasi Sains serta Kreativitas dan Inovasi Siswa SMP Kelas VII SMP. Thesis, Yogyakarta: UNY.

Yuliati, Y., \& Lestari, L. (2019). Penerapan Model Creative Problem Solving Untuk Meningkatkan Hasil Belajar Siswa Pasa Pembelajaran Ilmu Pengetahuan Alam di Sekolah Dasar. Jurnal Cakrawala Pendas, 5 (1): 32-39. 